Utah State University

DigitalCommons@USU

1983

\title{
The utilization of carbohydrates in aspen roots following partial or complete top removal
}

\author{
R.D. FitzGerald \\ J. Hoddinott
}

Follow this and additional works at: https://digitalcommons.usu.edu/aspen_bib

Part of the Forest Sciences Commons

\section{Recommended Citation}

FitzGerald, R.D. and Hoddinott, J., "The utilization of carbohydrates in aspen roots following partial or complete top removal" (1983). Aspen Bibliography. Paper 4174.

https://digitalcommons.usu.edu/aspen_bib/4174

This Article is brought to you for free and open access by the Aspen Research at DigitalCommons@USU. It has been accepted for inclusion in Aspen Bibliography by an authorized administrator of DigitalCommons@USU. For more information, please contact

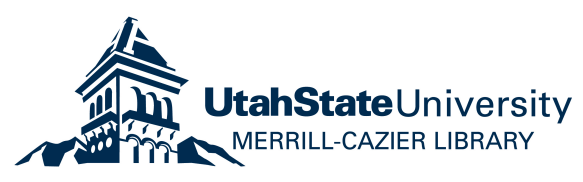




\title{
The utilization of carbohydrates in aspen roots following partial or complete top removal
}

\author{
R. D. FITzGerald \\ Department of Plant Science, University of Alberta, Edmonton. Alta.. Canada T6G $2 G 6$ \\ AND \\ J. HODDINOTT \\ Botany Department, University of Alberta, Edmonton, Alta., Canada T6G $2 G 6$
}

Received September 7, $1982^{2}$

Accepted March 21, 1983

FITZGERALD. R. D.. and J. HodDINOTT. 1983. The utilization of carbohydrates in aspen roots following partial or complete top removal. Can. J. For. Res. 13: 685-689.

The decline in carbohydrates in roots of aspen (Populus tremuloides Michx.) as a consequence of shoot production and the contribution of new shoots to root carbohydrate levels was investigated as part of a study of the factors controlling aspen regrowth following top removal. The level of nonstructural carbohydrates in the roots of young aspen shoots which had been clipped during the growing season was estimated at the commencement of the dormant season. Segments of the roots were then placed in growth cabinets and kept either in darkness or in one of two light regimes having equal quantum flux densities, but with quality akin to either normal sunlight or shade. Shoot growth in darkness was greater from roots taken from plots where clipping had been conducted in midseason rather than later in the season. suggesting that some carbohydrate replenishment had taken place in those plots. Carbohydrate concentration in roots placed in the three light regimes declined to approximately the same extent over the 8 weeks of the experiment, but total weight of shoots was greater in light than in darkness. which suggests that newly synthesized carbohydrates were retained in the tops for growth. While shoots in normal and shade quality light were not phenologically different, shoots in normal light had greater leaf development than shoots in shade light and were heavier. presumably as a consequence of the greater leaf development leading to a greater net photosynthesis. FITZGerald, R. D., et J. HoddinotT. 1983. The utilization of carbohydrates in aspen roots following partial or complete top
removal. Can. J. For. Res. 13: $685-689$.

Dans une étude des facteurs qui contrôlent le recrù du peuplier faux-tremble (Populus tremuloides Michx.) suite à l’ablation de la partie extérieure de la tige. les auteurs ont étudié l'abaissement des concentrations d’hydrates de carbone dans les racines suite à la production de rejets et la contribution de ces rejets à des concentrations d hydrates de carbone dans les racines. Au début de la période de dormance. on a estimé la concentration d'hydrates libres de carbone dans les racines de jeunes tiges émondées durant la saison de croissance. Des sections de racines placées dans des cellules de croissance ont été gardées à l'obscurité ou sous un de deux régimes de luminosité, à un quantum de flux lumineux de densité égale mais dont la qualité se rattachait à un ensoleillement normal ou à un ombrage. Les tiges gardées à l'obscurité ont crú davantage lorsqu'elles provenaient de racines prélevées dans des parcelles où l'émondage avait eu lieu à la mi-saison par rapport à celles où l'émondage a vait eu lieu plus tard. ce qui suggère que les hydrates de carbone s y étaient reconstitués. Sous les trois régimes de luminosité. la concentration d'hydrates de carbone dans les racines a diminué jusqu'à un niveau à peu près comparable durant les 8 semaines de l'expérience, mais le poids total des tiges était plus élevé chez celles qui s'étaient développees à la lumière que chez les autres, ce qui suggère que de nouveaux hydrates de carbone se sont synthétisés pour favoriser la croissance chez les parties extérieures des tiges. Les tiges ayant crù à la lumière normale et à l'ombre n étaient pas phénologiquement différentes: les tiges en luminosité normale avaient un développement plus poussé du feuillage que les tiges ayant crù à l'ombre: elles étaient aussi plus lourdes, probablement du fait qu'un développement plus poussé du feuillage conduit à un accroissement net de la photosynthèse.

[Traduit par le journal]

\section{Introduction}

Aspen (Populus tremuloides Michx.) produces suckers irregularly along shallow cordlike roots in re-

\footnotetext{
'Present address: Department of Agriculture, New South Wales, Agricultural Research Station. Glen Innes, New South Wales, 2370, Australia.

'Revised manuscript received March 14, 1983.
}

sponse to the stimulus associated with a change in the ratio of auxin to cytokinin (Wolter 1968; Schier $1978 b$ ). Since top removal stimulates suckering, it may result in a lowering of reserve carbohydrates, as Donart anc Cook (1970) showed with Rocky Mountain shrubs. Indeed, Berry and Stiell (1978) found that repeated annual removal of top growth eventually reduced aspen sucker vigour. Some replenishment of reserves between 
removal operations seems likely, since it took at least 7 years to exhaust the plants.

Schier and Zasada (1973) considered that when a developing shoot emerges aboveground, its dependence on stored carbohydrates will decline as the shoot begins to produce photosynthates. However, while the stem apex is actively growing, it may remain a net importer of carbohydrates (Larson and Dickson 1973), including, initially at least, mobile carbohydrates from the roots. As the shoot matures, the proportion of foliage made up of young expanding leaves (net importers) declines, but the stage in the development of the young aspen shoot at which net depletion of root carbohydrates ceases and replenishment commences is not established.

Following top removal, aspen suckers are stimulated to grow in vast numbers. Subdominant suckers are subject to shading from dominant suckers. As light passes through a canopy of foliage the ratio of radiant energy at 660 and $730 \mathrm{~nm}$ ( $\zeta$ ratio) is reduced (Holmes and Smith 1977), and there is a corresponding change in the form of the pigment phytochrome (Smith and Holmes 1977). Since the $\zeta$ ratio. through its influence on phytochrome, affects many aspects of photomorphogenesis (Mohr 1974: Holmes and Smith 1977) it may influence the development of subdominant (shaded) aspen suckers.

To investigate the role of aspen suckers in root carbohydrate depletion and subsequent replenishment, an experiment was conducted to determine, firstly, the effect of top removal at various times during the growing season on the concentration of total nonstructural carbohydrates (TNC) at the end of the season. Then, to separate the effects of carbohydrate mobilisation from its replenishment by photosynthesis, changes in the concentration of TNC associated with the development of shoots were studied by growing shoots in darkness and in light. Further, the effect on carbohydrate depletion and replenishment of maintaining shoots in far-red enriched (shade quality) light was also determined.

\section{Field piots}

\section{Methods}

A single clone of mature aspen growing at Kinsella in east central Alberta was burned in spring 1979. In early June, before any visible outgrowth of root primordia, it was divided into $2 \times 2 \mathrm{~m}$ plots marked out by narrow trenches $30 \mathrm{~cm}$ deep so that all surface roots were severed between plots. Shoots emerging on these plots were clipped to $50 \%$ of their height on one of three occasions (July 17. August 7, August 27) during 1979. Control plots were not clipped. There were three replications of the field plots.

Root sampling and preparation

Seventy-two surface roots (maximum depth $5 \mathrm{~cm}$ ) from clipped and unclipped plots for the three clipping dates were dug up on October 8, 1979, after onset of dormancy taking

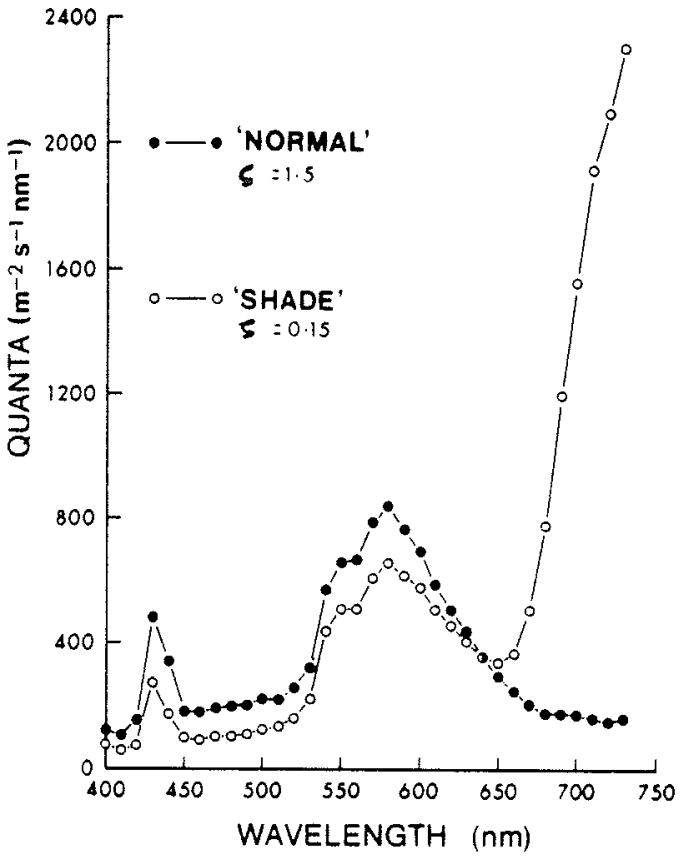

FiG. 1. Light energy (quanta) in the 400- to 730-nm range in the "normal" and "shade" growth cabinets.

four roots per plot. Roots sampled were between 0.5 and 1.5 $\mathrm{cm}$ in diameter. A 2- to 3-cm segment was cut from each end of these roots and immediately placed in dry ice. prior to analysis for TNC.

After removal of segments from the extremities, each root was wrapped in a moistened towel and returned to the laboratory where it was divided into three segments $8-10 \mathrm{~cm}$ long. Each segment was labelled and soaked for $5 \mathrm{~min}$ in a fungicide solution (2.2\% methyl mercury dicyandiamide). After sealing the cut surfaces with melted paraffin, it was planted $1-1.5 \mathrm{~cm}$ deep in moistened vermiculite (Schier 1978a), in one of three growth cabinets. One-third of each root was placed in each cabinet

\section{Light environment treatments}

One cabinet was maintained in total darkness. Light in the remaining two was similar in quality to either normal sunlight ("normal") or to light under an aspen forest canopy ("shade") (Holmes and Smith 1977). Quantum flux density in these cabinets was balanced for photosynthetically active radiation at $195 \mu \mathrm{E} \mathrm{m}^{-2} \mathrm{~s}^{-1}$, with quanta in the red and far-red regions contrasting (Fig. 1), so that $\zeta$ ratios for normal and shade cabinets were 1.5 and 0.15 respectively. The "normal" cabinet was lit by a series of fluorescent lamps. In the "shade" cabinet some fluorescent tubes were replaced by a highintensity quartz iodide lamp. covered with a red filter. Photoperiod was $16 \mathrm{~h}$. Temperature was maintained at $25: 15^{\circ} \mathrm{C}$ for $16: 8 \mathrm{~h}$ (Schier and Zasada 1973), and relative humidity was approximately $70 \%$. Plants were watered daily.

After approximately 8 weeks, plants growing in darkness began to die. Consequently all plants were harvested and shoot growth characteristics were recorded. Stems, leaves, and roots were then oven-dried to obtain dry weights. Root 
TABLE 1. Root TNC at sampling in October. mean number, total length, and total weight per root of aspen shoots growing in darkness from excised roots taken from four field clipping time treatments

\begin{tabular}{lccccc}
\hline & \multicolumn{5}{c}{ Clipping time } \\
\cline { 2 - 6 } & Unclipped & July 17 & August 7 & August 27 & SE \\
\hline TNC & 10.1 & 10.4 & 10.0 & 11.6 & 5.2 \\
Number & $7.0 a$ & $7.7 a$ & $5.8 a b$ & $3.9 b$ & 1.1 \\
Length $(\mathrm{mm})$ & $971 a$ & $760 a$ & $236 b$ & $404 b$ & 52 \\
Weight $(\mathrm{mg})$ & $189 a$ & $176 a$ & $32 b$ & $80 b$ & 26 \\
\hline Nore: Means within rows followed by the same letter are not vgnticantiv sifferent $(P=0$ 0 05)
\end{tabular}

segments were placed in a deep freeze $\left(-40^{\circ} \mathrm{C}\right.$ ) prior to anallysis for TNC.

\section{Carbohydrate analysis}

Analysis followed the extraction procedure of Smith (1969). The concentration of the extracted reducing sugars was determined by spectrophotometry using 3.5-dinitrosalicylate solution as a colouring agent. The concentration of carbohydrates was expressed as a percentage of the dry weight of root tissue.

\section{Statistical analysis}

The data were analysed as split plots. Clipping time treatment provided "main" effects, these being split for growth cabinet effects. Where appropriate, the effect of parent root diameter, or new root weight. was included in the model. as a covariate. Means are least square means calculated from the coefficients fitted to the regression model

\section{Results}

\section{Clipping time}

Clipping had no significant effect on TNC in roots sampled in October (Table 1) as analysed in the laboratory. However, in darkness. roots from unclipped field plots and from the July-clipped plots produced a greater length and mass of stem tissue than roots from later clipped plots. There was a similar trend in shoot number. These effects were not evident in shoots grown in light.

\section{Light environment effects}

TNC levels declined as shoots were produced in growth cabinets, but neither the final TNC level nor the amount of change were different between growth cabinet treatments. Regression of root diameter on TNC at commencement was significant, and explained $8 \%$ of TNC variation $\left(r^{2}=0.08\right)$.

Morphological effects of cabinet treatments are shown in Table ?. There were no differences in numbers of shoots $(>1 \mathrm{~mm}$ ) produced per root in each growth cabinet.

Dark-grown shoots were taller but lighter (thinner) than were light-grown shoots. While weight of stems was not significantly different among the three light treatments, a greater weight of leaves was produced per root in normal light than shade light, which meant that total weight of shoots per root was heaviest in normal light. lightest in the dark. and intermediate in shade light. The leaf : stem ratio reflected the greater weight of leaves under normal light.

New roots were heaviest in normal light, lightest in darkness, and intermediate in shade light. Resultant shoot: root ratios indicate the partitioning of carbohydrates in dark-grown plants, towards top growth.

\section{Discussion}

In darkness. roots from unclipped field plots and from the July-clipped plots produced longer and heavier stem material than roots from later clipped plots. Shoots growing in darkness are dependent on stored carbohydrates. The result suggests that unclipped and earlyclipped plants had more carbohydrates available for growth than later clipped plants. Early-clipped plants may have had sufficient growing season left after clipping for some carbohydrate replenishment to take place.

The absence of differences between clipping treatments in TNC as analysed in the laboratory may have been associated with initial drying of the root tissue. The time taken to reach dryness and commence carbohydrate breakdown in an oven at $100^{\circ} \mathrm{C}$ will vary where tissue varies in bulk (Smith 1969). Hence the $8 \%$ TNC variation associated with root diameter may have obscured small differences in TNC between clipping treatments. The problem is obviated between growth cabinet treatments since each cabinet contained a third of each root, and therefore encompassed the full range of variation in root diameter.

Unlike the plants clipped in the field. rapid carbohydrate replenishment did not occur in roots supporting shoots in growth cabinets. Instead, the new shoots growing in light apparently retained their photosynthates for top growth. The excess weight of shoots grown in light over those grown in darkness must be attributable directly or indirectly to photosynthesis. Shoot weight in "shade" light was doubled and in 
TABLE 2. Morphological effects of three light environments on aspen shoots at harvest

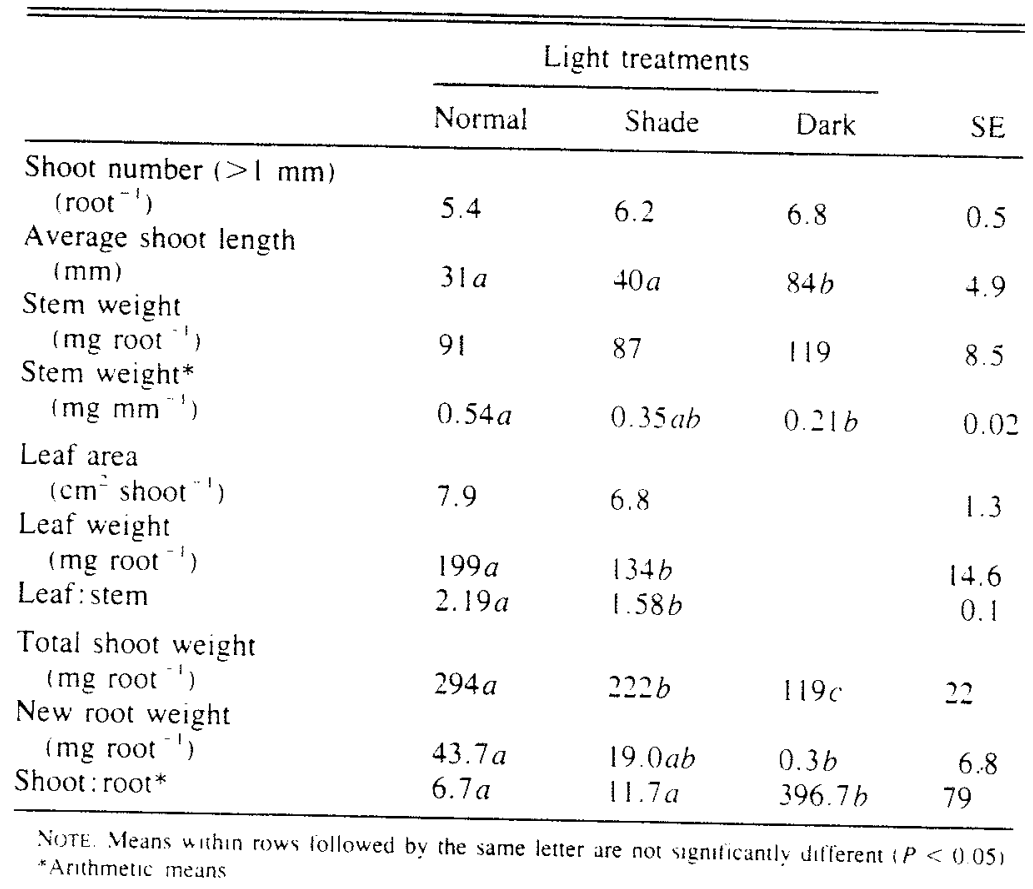

"normal" light almost trebled. This retention of photosynthates within the actively growing shoot corresponds with the findings of Larson and Dickson (1973) for $P$. deltoides, and Donnelly (1974) for mature trees ( $P$. grandidentata).

There were a number of important differences between plants in field plots and plants in growth cabinets which may account for the difference in the time period required for carbohydrate restoration to commence. In the field only the upper half of the plants was removed. leaving mature (exporting) leaves intact. The interruption to basipetal transport from these leaves may have been relatively short. whereas in the growth chamber there was no possible source of photosynthate until new shoots grew and began photosynthate export. Other differences between field plots and growth cabinets likely to alter the rate at which carbohydrates are transported to parent roots include a difference in sink strength between actively growing roots in the field and excised roots in the growth cabinet. and the low light intensity (approximately $20 \%$ of normal) maintained in growth cabinets compared with normal field intensity.

Light quality in the experiment had no effect on final TNC levels. although it did appear to be controlling some aspects of adaptation to shade, presumably through the action of phytochrome (Mohr 1974: Holmes and Smith 1977). Greater leaf development in plants in "normal" light enabled those plants to fix more carbon, and consecuently grow taster than plants in "shade" light. They also produced more adventitious roots. While plants grown in "shade" had lower leat: stem and higher shoot: root ratios than plants in "normal" light, they were not phenologically different. This suggests that the difference in performance of shaded and unshaded suckers in the field may be a response to light intensity as well as light quality.

BERRY. A B., and W. M. STIELl. 1978. Effect of rotation length on productivity of aspen sucker stands. For. Chron. 54: $265-267$

DONART. G. B., and C. W. COOK. 1970. Carbohydrate reserve content of mountain range plants following defoliation and regrowth. J. Range Manage 22: 15-19.

DoNivelly. J. R. 1974. Seasonal changes in photosynthate transport within elongating shoots of Populus grandidentata. Can. J. Bot. 52: 2547-2559.

Hol.Mes. M. G.. and H. S.MITH. 1977. The function of phytochrome in the natural environment-IV Light quality and plant development. Photochem. Photobiol. 25: $551-557$.

LARSON, P. R.. and R. E. DiCKSON. 1973. Distribution of imported ${ }^{14} \mathrm{C}$ in developing leaves of eastern cottonwood according to phyllotaxy. Planta. 111: 95-112.

MOHR. H. 1974. The role of phytochrome in controlling enzyme levels in plants. In Biochemistry of cell differentiation. Edited by J. Paul. M.T.P. International Review of Science. Vol. 9. Butterworths, London. pp. 37-81.

SCHIER. G. A. 1978a. Vegetative propagation of Rocky Mountain aspen. U.S. For. Serv. Gen. Tech. Rep. INT-44. $1978 \mathrm{~b}$. Root suckering in young aspen, girdled, defoliated and decapitated at various seasons. Proc.. Fifth 
North Am. For. Biol. Workshop. Edited by C. A. Hollis and A. E. Squillace. University of Florida. Gainesville, and U.S. Department of Agriculture Forest Service. pp. 259-267.

SCHIER. G. A., and J. C. ZaSADA. 1973. Role of carbohydrate reserves in the development of root suckers in Populus tremuloides. Can. J. For. Res. 3: 243-250.

SMITH, D. 1969. Removing and analysing total nonstructural carbohydrates from plant tissue. Res. Div. Coll. Agric Life Sci. Univ. Wisconsin. Res. Rep. 41

SMITH, H., and M. G. HOLMES. 1977. The function of phytochrome in the natural environment-IIl Measurement and calculation of phytochrome photoequilibria. Photochem. Photobiol. 25: 547-550.

WOLTER. K. E. 1968. Root and shoot initiation in aspen callus cultures. Nature (London). 219: $509-510$.

\title{
Analyses of mineral elements in vegetative buds and needles from young and old trees of Picea abies
}

\author{
SARA VON ARNOLD \\ Institute of Physiological Botany, University of Uppsala, Box 540, S-751 21. Uppsala, Sweden \\ AND \\ GODFried M. ROOMANS \\ Wenner-Grens Institute, University of Stockholm, S-113 45. Stockholm, Sweden \\ Received November 29. $1982^{1}$ \\ Accepted March 23, 1983
}

VON ARNOLD, S., and G. M. ROOMANS. 1983. Analyses of mineral elements in vegetative buds and needles from young and old trees of Picea abies. Can. J. For. Res, 13: 689-693

The mineral contents of vegetative buds and needles collected from young plants and old trees of Picea abies (L.) Karst. were determined. It was found that the contents of $\mathrm{Cl}, \mathrm{K}$. and $\mathrm{Na}$ were significantly higher in buds from old trees than in buds from young plants. Since the $\mathrm{Na}$ concentration increased more with age than the $\mathrm{K}$ concentration, the $\mathrm{K}: \mathrm{Na}$ ratio decreased with age. In addition, dry weight was significantly higher in buds from old trees than in buds from young plants. Similar age-dependent differences could not be observed in the needle tissue.

VON ARNOLD, S., et G. M. RoOmans. 1983. Analyses of mineral elements in vegetative buds and needles from young and old trees of Picea abies. Can. J. For. Res. 13:689-693.

On a déterminé le contenu minéral de bourgeons végétatifs et d'aiguilles prélevés sur de jeunes plants et de vieux arbres de l'espèce Picea abies (L.) Karst. Le contenu en $\mathrm{Cl}, \mathrm{K}$ et $\mathrm{Na}$ est significativement plus élevé dans les bourgeons des vieux arbres que chez ceux des jeunes plants. Comme la concentration en $\mathrm{Na}$ augmente plus avec l'âge que la concentration en $\mathrm{K}$. le rapport $\mathrm{K}: \mathrm{Na}$ décroît avec l'âge. Le poids sec des bourgeons est significativement plus élevé chez ceux des vieux arbres que chez ceux des jeunes plants. Quant aux tissus des aiguilles, on n'observe pas de telles différences reliées avec l'âge.

[Traduit par le joumal]

\section{Introduction}

Trees, which have a long generation time, can be propagated vegetatively to obtain genetic improvement in a shorter time than is possible by sexual propagation (Lundkvist and Gullberg 1981). Rooting of cuttings is the most common method of vegetative propagation. However, with increasing age there is a gradual loss of the rooting potential and increased plagiotropism. When trees are old enough to demonstrate desirable qualities, they often are too old to be propagated by cuttings. Before old elite trees can be propagated by cuttings on a large scale, problems related to aging in the selected material have to be overcome. To solve

\footnotetext{
'Revised manuscript received March 14, 1983.
}

these problems it is necessary to get a better understanding of the chemical-physiological differences between juvenile and mature tissue.

Juvenile leaves of Hedera helix $L$. have a higher mineral content (mineral weight/ash weight) than adult leaves (Millikan and Jankiewicz 1966). On the other hand the trace element level (mineral weight/dry weight) is higher in needles from old trees of Picea rubens Sarg. than in needles from young trees (MacLean and Robertson 1981). In callus of Pseudotsuga menziesii (Mirb.) Franco the potassium and sodium content (mineral weight/dry weight) increase considerably after many subcultures, since the sodium content increases more there is a drop in the potassium: sodium ratio (Johnson and Carlson 1977). A similar decrease in the potassium: sodium ratio occurs during 